\title{
HUBUNGAN USIA IBU HAMIL DENGAN KEJADIAN PERSALINAN PREMATUR DI RSUD PANEMBAHAN SENOPATI BANTUL YOGYAKARTA
}

\author{
RELATIONSHIP BETWEEN THE AGE OF \\ PREGNANT WOMEN AND PREMATURE LABOR IN \\ PANEMBAHAN SENOPATI REGIONAL PUBLIC \\ HOSPITAL, BANTUL, \\ YOGYAKARTA
}

\author{
Halimah Rosyidah ${ }^{1}$, RR Viantika Kusumasari ${ }^{2}$, Dian Nur Adkhana ${ }^{3}$. \\ ${ }^{123}$ STIKes Surya Global Yogyakarta.
}

\begin{abstract}
ABSTRAK
Persalinan prematur menjadi masalah global yang terjadi di dunia, Indonesia menduduki posisi kelima tertinggi. Penyebab persalinan prematur multikompleks, salah satu faktornya adalah usia. Usia ibu beresiko ( $<20$ dan $>35$ tahun), sedangkan usia tidak beresiko (20-35 tahun). Tujuan penelitian ini adalah mengetahui hubungan antara usia ibu hamil dengan kejadian persalinan prematur. Penelitian ini menggunakan desain deskriptif korelasi dengan pendekatan cross sectional. Pengambilan sampel menggunakan teknik purposive sampling dengan jumlah sampel yaitu 97 ibu hamil yang mengalami persalinan prematur. Peneliti menggunakan studi dokumentasi dari rekam medis RSUD Panembahan Senopati Bantul Yogyakarta selama periode bulan Januari-Desember 2018. Analisis data menggunakan uji Kendall-Tau. Menghasilkan nilai $p$ value $0,046(<0,05)$, yang menunjukan terdapat hubungan antara usia ibu hamil dengan kejadian persalinan prematur. Kesimpulan : Ada hubungan antara usia ibu hamil dengan kejadian persalinan prematur di RSUD Panembahan Senopati Bantul Yogyakarta.
\end{abstract}

Kata kunci : Usia ibu hamil, Persalinan prematur.

\section{ABSTRACT}

Premature delivery to global literature happening in the world, Indonesia occupies the fifth highest position. The cause of Multicomplex premature childbirth, one of the factors is age. Mother's age is at risk (<20 and $>35$ years), while age is not at risk (20-35 years). The purpose of this research is knowing the relationship between the age of pregnant women and the occurrence of premature labor. The study uses a descriptive correlation design with the Cross sectional approach. Sampling uses purposive sampling techniques with samples of 97 expectant mothers who have premature labor. Researchers use documentation studies from the medical record of Panembahan Senopati Yogyakarta in Bantul period from January to December 2018. Data analysis using Kendall-tau test. 
Generates a value of $P$ Value $0046(<0$, 05), which indicates there is a relationship between the age of pregnant women and the incidence of premature labor. Conclusion: There is a relationship between the age of pregnant women with the occurrence of premature delivery in the hospital Panembahan Senopati Bantul Yogyakarta.

Keywords: Age of pregnant women, premature delivery.

\begin{tabular}{ll}
\hline Alamat Korespondensi & $\begin{array}{l}\text { : STIKes Surya Global Yogyakarta } \\
\text { Email }\end{array}$ \\
\hline
\end{tabular}

\section{PENDAHULUAN}

Angka Kematian Bayi (AKB) merupakan indikator pertama dalam menentukan derajat kesehatan anak sekaligus sebagai cerminan dari status kesehatan masyarakat (Depkes, 2011). Kematian perinatal disebabkan oleh prematuritas sebesar 75\% (Krisnadi at el., 2009) Menurut WHO (2015) kematian perinatal di dunia terdapat 2,68 juta jiwa, penyebab tertinggi yaitu persalinan prematur sebesar 947.000 bayi (InfoDATIN, 2018). Persalinan prematur adalah masalah global yang terjadi di berbagai negara di dunia. Terdapat sepuluh negara dengan kasus persalinan prematur tertinggi di dunia, Indonesia menduduki peringkat kelima tertinggi di dunia (WHO, 2012).

Data AKB di Indonesia menurut SDKI (2012) terdapat lima peringkat tertinggi yaitu kalimantan timur, DKI Jakarta, Riau, Sulawesi Selatan dan Daerah Istimewa Yogyakarta (DIY). Dari data tersebut dinyatakan bahwa DIY belum mampu memenuhi target MDGs karena AKB tahun 2012 masih berada di angka 25 per 1000 kelahiran hidup (Dinkes RI, 2017). Data AKB tertinggi di Kabupaten Bantul 108 kasus dan terendah di Kota Yogyakarta 33 kasus (Dinkes DIY, 2017). Persalinan prematur di Kabupaten Bantul tahun 2017 terdapat 265 kasus dari 27 puskesmas di Bantul. Angka persalinan prematur tertinggi yaitu wilayah Puskesmas Jetis 1 sebesar 21 kasus dan Puskesmas Piyungan sebesar 21 kasus (Dinkes Bantul, 2017).

Persalinan prematur merupakan persalinan yang terjadi pada usia kehamilan kurang dari 37 minggu atau dengan berat janin kurang dari 2.500 gram. Dibandingkan dengan bayi yang lahir cukup bulan, bayi prematur terutama yang lahir dengan usia kehamilan $<32$ minggu mempunyai risiko kematian 70 kali lebih tinggi, karena mereka mempunyai kesulitan untuk beradaptasi dengan kehidupan setelah lahir akibat ketidakmatangan sistem organ tubuhnya (Krisnadi at el., 2009). Dalam agama Islam membahas tentang batasan umur kehamilan prematur menurut Ibnu katsir rahimahullah berkata ketika menafsirkan surat Al - Baqarah ayat 223: و هو استنباط قوي صحيح. وو افقه عليه [ البقرة: 233] على أن أقل مدة الحمل ستة أنثهر،

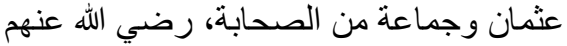
"Bahwa batasan minimal lama waktu kehamilaan adalah 6 bulan". Ini adalah kesimpulan yang kokoh dan shahih. Disepakati oleh Ustman dan sejumlah sahabat radhialhu 'anhu.

Menurut Al-Qur'an yang dijelaskan bahwa dikatakan persalinan prematur apabila usia kehamilan minimal 6 bulan atau 24 minggu. Persalinan prematur merupakan salah satu faktor terjadinya kematian perinatal. Selain itu dampak yang 
bisa terjadi bagi bayi prematur sering disertai dengan kelainan, baik jangka pendek maupun jangka panjang. Kelainan jangka pendek yang paling sering terjadi adalah RDS (Respiratory Distress Syndrome), perdarahan intraperiventrikular, NEC (Necrotizing Entero Cilitis), displasi bronko-pulmoner, sepsis, dan paten duktus arteriosus (Prawirohardjo, 2016). Penyebab persalinan prematur bukan hanya tunggal tetapi multi kompleks. Banyak faktor yang menyebabkan terjadinya persalinan prematur diantaranya yaitu faktor idiopatik, iatrogenic, sosiodemografik (kecemasan, depresi, stress, perilaku ibu, pekerjaan ibu, dan usia ibu), faktor maternal (inkompetensia serviks, kelainan uterus, riwayat reproduksi, pemeriksaan kehamilan, skoring risiko, dan penyakit penyerta), genetik, dan infeksi (Krisnadi et al., 2009).

Hasil beberapa peneliti mengatakan bahwa usia ibu hamil memiliki hubungan dengan kejadian persalinan prematur (Wahyuni. 2017; Hidayati, 2016; Niswah, 2016). Usia pada rentang $<20$ tahun dan $>35$ tahun merupakan faktor risiko tinggi. (Nugroho, 2012). Ibu hamil usia reproduktif merupakan usia aman untuk kehamilan dan persalinan adalah usia 20-35 tahun (Depkes, 2009). Akan tetapi, berdasarkan beberapa penelitian mengungkapkan bahwa usia reproduktif (20-35 tahun) lebih banyak mengalami kejadian persalinan prematur daripada usia berisiko ( $<20$ dan $>35$ tahun) (Anasari \& Pantiawati, 2016; Ningrum et al., 2017).

Persalinan prematur tidak selalu terjadi pada ibu yang berusia risiko $(<20$ dan $>35$ tahun), tetapi juga dapt terjadi pada ibu tidak berisiko (20-35 tahun) dalam kurun reproduksi sehat. Hal ini disebabkan karena persalinan preterm dipengaruhi oleh banyak faktor lain seperti paritas banyak, kehamilan kembar, hidromnion, plasenta previa, preeklamsia-eklampsia, KPD, anemia, status gizi, inkompetensi serviks, aktivitas pekerjaan, riwayat obstetric, stress pskologi, merokok, minum alcohol, penyakit penyerta, dan infeksi (Saifuddin, 2007 dalam Anasari \& Pantiawati, 2016).

Berdasarkan hasil studi pendahuluan yang dilakukan oleh peneliti di RSUD Panembahan Senopati Bantul Yogyakarta terdapat 2.050 ibu yang melahirkan pada tahun 2018. Dari $2.050 \mathrm{ibu}$ yang melahirkan, terdapat $130 \mathrm{ibu}$ hamil yang mengalami persalinan prematur, mayoritas pada rentang usia reproduktif (20-35 tahun) sebanyak 105 ibu hamil yang mengalami persalinan prematur. Berdasarkan latar belakang diatas usia aman lebih banyak mengalami persalinan prematur daripada usia berisiko. Tujuan penelitian ini adalah untuk mengetahui adakah hubungan antara usia ibu hamil dengan kejadian persalinan prematur, serta mengetahui kejadian usia ibu hamil dan persalinan prematur di RSUD Panembahan Senopati Bantul Yogyakarta.

\section{METODE PENELITIAN}

Penelitian ini dilakukan pada tanggal 10-22 Juni 2019. Penelitian ini menggunakan desain deskriptif korelasi dengan pendekatan cross sectional. Pengambilan sampel menggunakan teknik purposive sampling dengan jumlah sampel yaitu $97 \mathrm{ibu}$ hamil yang mengalami persalinan prematur. Instrumen studi dokumentasi dari data rekam medis RSUD Panembahan Senopati Bantul Yogyakarta pada bulan Januari-Desember 2018. Adapun kriteria inklusi yang digunakan yaitu ibu melahirkan dengan umur kehamilan $<28$ sampai $<37$ minggu 
dan sumber data rekam medik yang lengkap. Sedangkan kriteria ekslusi yaitu kehamilan dengan penyakit medis penyerta seperti Kehamilan dengan penyakit medis penyerta seperti DM, Anemia, penyakit jantung, hipertensi, kelainan uterus, kehamilan kembar, inkompetensi serviks dan kehamilan dengan infeksi, dan faktor genetik. Analisis data menggunakan uji Kendall-Tau.

\section{Hasil Penelitian}

\section{HASIL DAN DISKUSI}

Penelitian ini dilakukan di RSUD Panembahan Senopati Bantul Yogyakarta menggunakan sumber data sekunder rekam medis rumah sakit.

\section{Tabel 1 Distribusi Frekuensi Karakteristik Responden di Ruang Bersalin RSUD Panembahan Senopati Bantul Yogyakarta}

\begin{tabular}{|c|c|c|c|}
\hline No. & Karakteristik Responden & Frekuensi & Persentase (\%) \\
\hline 1. & $\begin{array}{l}\text { Pendidikan } \\
\text { a. Dasar (SD-SMP) } \\
\text { b. Menengah (SMA) } \\
\text { c. Tinggi (Perguruan Tinggi) }\end{array}$ & $\begin{array}{l}25 \\
56 \\
16\end{array}$ & $\begin{array}{l}25,8 \\
57,7 \\
16,5\end{array}$ \\
\hline 2. & $\begin{array}{l}\text { Riwayat Prematur } \\
\text { a. Pernah } \\
\text { b. Tidak pernah }\end{array}$ & $\begin{array}{c}6 \\
91\end{array}$ & $\begin{array}{c}6,2 \\
93,8\end{array}$ \\
\hline 3. & $\begin{array}{l}\text { Paritas } \\
\text { a. Primipara } \\
\text { b. Multipara } \\
\text { c. Grandemultipara }\end{array}$ & $\begin{array}{c}77 \\
20 \\
0\end{array}$ & $\begin{array}{c}79,4 \\
20,6 \\
0\end{array}$ \\
\hline 4. & $\begin{array}{l}\text { Abortus } \\
\text { a. Ya } \\
\text { b. Tidak }\end{array}$ & $\begin{array}{l}13 \\
84\end{array}$ & $\begin{array}{l}13,4 \\
86,6\end{array}$ \\
\hline 5. & $\begin{array}{l}\text { Ketuban Pecah Dini (KPD) } \\
\text { a. Ya } \\
\text { b. Tidak }\end{array}$ & $\begin{array}{l}14 \\
83\end{array}$ & $\begin{array}{l}14,4 \\
85,6\end{array}$ \\
\hline 6. & $\begin{array}{l}\text { Antanatal Care (ANC) } \\
\text { a. Teratur } \\
\text { b. Tidak teratur }\end{array}$ & $\begin{array}{l}78 \\
19\end{array}$ & $\begin{array}{l}80,4 \\
19,6\end{array}$ \\
\hline & Total & 97 & 100,0 \\
\hline
\end{tabular}

Hasil analisis deskriptif pada tabel 4.1 menunjukkan bahwa karakteristik responden di RSUD Panembahan Senopati Bantul Yogyakarta yaitu berdasarkan riwayat pendidikan mayoritas memiliki pendidikan menengah sebanyak 56 responden $(57,87 \%)$, riwayat persalinan prematur sebelumnya mayoritas tidak pernah mengalami persalinan prematur sebelumnya sebanyak 91 responden $(93,8 \%)$, riwayat paritas mayoritas mengalami kehamilan primipara sebanyak 77 responden (79,4\%), mengalami abortus sebanyak 84 responden $(86,6 \%)$, mengalami ketuban pecah dini (KPD) sebanyak 83 responden $(85,6 \%)$ dan terdapat 78 responden $(80,4 \%)$ yang melakukan pemeriksaan kesehatan (Antanatal Care) secara teratur ( $>4$ kali) selama kehamilan. 
Tabel 2 Usia Ibu Hamil di RSUD Panembahan Senopati Bantul Yogyakarta

\begin{tabular}{ccc}
\hline $\begin{array}{c}\text { Usia ibu } \\
\text { hamil }\end{array}$ & Frekuensi & $\begin{array}{c}\text { Persentase } \\
\mathbf{( \% )}\end{array}$ \\
\hline Usia muda & 8 & 8,2 \\
Usia & 68 & 70,1 \\
reproduktif & 21 & 21,6 \\
Usia tua & & 100,0 \\
\hline Total & 97 & \\
\hline
\end{tabular}

Pada tabel 2 menunjukkan bahwa 97 responden mayoritas memiliki usia reproduktif sebanyak 68 responden $(70,1 \%)$

Tabel 3 Persalinan Prematur di RSUD Panembahan Senopati Bantul

\begin{tabular}{ccc}
\multicolumn{3}{c}{ Yogyakarta } \\
\hline Preterm & $\begin{array}{c}\text { Frekuen } \\
\text { si }\end{array}$ & $\begin{array}{c}\text { Persentase } \\
(\mathbf{\%})\end{array}$ \\
\hline$<28 \mathrm{mg}$ & 10 & 10,3 \\
$28-<32 \mathrm{mg}$ & 19 & 19,6 \\
$32-<37 \mathrm{mg}$ & 68 & 70,1 \\
\hline Total & 97 & 100,0 \\
\hline
\end{tabular}

Pada tabel 3 menunjukan hasil bahwa mayoritas responden mengalami persalinan prematur sedang atau akhir sebanyak 68 responden (70,1\%).

Tabel 4 Hubungan Usia Ibu Hamil dengan Kejadian Persalinan Prematur di RSUD Panembahan Senopati Bantul Yogyakarta

\begin{tabular}{cccc}
\hline & \multicolumn{1}{c}{ Usia } & Preterm \\
\hline Usia & $\begin{array}{c}\text { Correlatio } \\
n \\
\text { Coefficient } \\
\text { Sig. }(2- \\
\text { tailed) } \\
N\end{array}$ & 1.000 & $-.192^{*}$ \\
\hline $\begin{array}{c}\text { Persalin } \\
\text { an } \\
\text { prematu } \\
\mathbf{r}\end{array}$ & $\begin{array}{c}\text { Correlatio } \\
n\end{array}$ & $.192^{*}$ & .046 \\
& $\begin{array}{c}\text { Coefficient } \\
\text { Sig. }(2- \\
\text { tailed }) \\
N\end{array}$ & .046 & 97 \\
\hline & & 97 & 97 \\
\hline
\end{tabular}

Tabel 4 menunjukan bahwa terdapat hubungan antara usia ibu hamil dengan kejadian persalinan prematur di RSUD Panembahan Senopati Bantul dengan nilai koefesien korelasi sebesar $-0,192 *$ dan nilai sig $0,046(p<0,05)$ yang berarti Ha diterima dan Ho ditolak.

\section{Diskusi pembahasan}

\section{a. Usia Ibu Hamil di RSUD Panembahan Senopati Bantul Yogyakarta}


Usia reproduktif (20-35 tahun) adalah usia yang sehat dan aman untuk kehamilan dan persalinan. Hal ini sejalan dengan penelitian Anasari dan Pantiawati (2016) menyatakan bahwa usia tidak berisiko (20-35 tahun) lebih dominan daripada usia berisiko ( $<20$ dan $>35$ tahun) mengalami persalinan prematur. Menurut Depkes (2009) menyatakan bahwa usia reproduktif atau usia wanita reproduksi sehat diketahui bahwa usia aman untuk kehamilan dan persalinan adalah 20-35 tahun. Usia reproduktif untuk menjalankan proses kehamilan karena sistem reproduksi (siklus reproduksi sudah teratur) dan organ reproduksi sudah matang (endometrium) sudah sempurna dalam menjalankan fungsinya (BKKBN, 2015).

Akan tetapi, hasil penelitian ini usia reproduktif lebih dominan mempengaruhi persalinan prematur dikarenakan kurangnya ilmu pengetahuan tentang menjaga kesehatan serta pencegahan terjadinya gangguan persalinan selama masa kehamilan. Semakin tinggi tingkat pendidikan seseorang maka semakin mudah untuk menerima informasi sehingga kemampuan ibu dalam berfikir lebih rasional. Berdasarkan karakteristik responden mayoritas tingkat pendidikan menengah (SMA). Hal ini sejalan dengan penelitian Oroh et al., (2015) latar belakang ibu yang rendah menjadikan kurangnya pengetahuan tentang kesehatan ibu hamil, sehingga mereka tidak mengetahui cara menjaga kesehatan ibu terutama pada masa kehamilan.

Sesuai dengan teori Nugroho (2012) yang menyatakan bahwa kejadian persalinan prematur dipengaruhi oleh usia berisiko $(<20$ tahun dan $>35$ tahun) dan usia tidak berisiko (20-35 tahun). Apabila usia tidak berisiko mengalami persalinan prematur, bisa terjadi karena terdapat faktor lain yang mempengaruhi persalinan prematur diantaranya seperti fisik ibu yang tidak sehat, merokok, riwayat kehamilan, kesehatan dan kondisi janin, psikologi, bayi kembar, PMS, adanya infeksi, terlilit tali pusat, mengalami trauma, kelainan bentuk rahim dan serviks lunak.

\section{b. Persalinan Prematur di RSUD Panembahan Senopati Bantul Yogyakarta}

Persalinan prematur pada rentang sedang atau akhir yaitu umur kehamilan 32 minggu sampai kurang dari 37 minggu. Hal ini sejalan dengan beberapa penelitian yaitu menyatakan bahwa kelompok prematur sedang dan prematur akhir lebih dominan daripada kelompok prematur yang lainnya (Binalole $e t$ al., 2015; Zainal et al., 2019). Persalinan prematur sedang atau akhir (20-35 tahun) merupakan rentang usia kehamilan yang baik untuk kategori prematur. Hal ini sesuai dengan teori menurut WHO (2012) yaitu berdasarkan ukuran proporsi kategori persalinan prematur sebagai berikut : prematur ektrim (extremely preterm) sebesar 5,2\%, sangat prematur (very preterm) sebesar $10,4 \%$, dan prematur sedang atau akhir (moderate to late) sebesar $84,3 \%$. Klasifikasi persalinan prematur pada rentang persalinan prematur sedang atau akhir (32-<37 minggu) merupakan klasifikasi yang baik. Kesulitan utama dalam persalinan prematur adalah perawatan bayi pretem, semakin muda kehamilannya maka semakin besar angka mordibitas dan mortalitas (Indah et al., 2019). 


\section{c. Hubungan Usia Ibu Hamil dengan Kejadian Persalinan Prematur di RSUD Panembahan Senopati Bantul Yogyakarta}

Hal ini sejalan dengan beberapa penelitian menunjukkan bahwa usia memiliki faktor yang signifikan mengalami persalinan prematur (Sulistriarini dan Berlina, 2016; Wahyuni 2017). Sesuai dengan teori Krisnadi et al., (2016) bahwa usia menjadi salah satu faktor yang mempengaruhi persalinan prematur. Menurut peneliti, usia ibu merupakan faktor yang mempengaruhi persalinan prematur. Pada usia $<20$ tahun merupakan usia yang masih terlalu dini karena organ reproduksi belum matang, sedangkan usia $>35$ tahun merupakan usia lanjut yang memiliki resiko komplikasi lebih tinggi karena terjadinya penurunan fungsi organ tubuh.

Sesuai dengan hasil penelitian oleh Wahyuni (2017) bahwa secara fisik alat reproduki pada usia $<20$ tahun belum terbentuk sempurna, pada umumnya rahim rahim masih relatif kecil karena pembentukan belum sempurna dan pertumbuhan tulang panggul belum belum cukup lebar, meningkatnya risiko komplikasi maternal selama kehamilan dan persalinan, serta risiko persalinan prematur. Sedangkan pada usia $>35$ tahun risiko terjadinya komplikasi kehamilan juga meningkat yang berdampak pada morbiditas dan mortalitas bayi yang akan dilahirkan.

Berdasarkan keeratan hubungan pada penelitian ini memiliki sifat korelasi yang negatif (arahnya timbal balik) dan sangat lemah. Artinya usia ibu hamil merupakan faktor usia yang memiliki nilai signifikan kecil, dengan kata lain terdapat faktor lain yang memiliki korelasi lebih signifikan mengalami persalinan prematur di RSUD Panembahan Senopati Bantul Yogyakarta. Hal ini sejalan dengan teori Krisnadi et al., (2009) yang menyatakan bahwa terdapat multikompleks faktor yang mempengaruhi persalinan prematur diantaranya faktor idiopatik, iatrogenik, sosio-demografi (kecemasan, depresi, stres, perilaku ibu, pekerjaan ibu, usia ibu), maternal (inkompetensi serviks, kelainan uterus, riwayat kesehatan, riwayat prematur sebelumnya, pemeriksaan kesehatan, skoring rendah, penyakit medis dan penyertanya), infeksi dan genetik.

Menurut pendapat peneliti, berdasarkan karakteristik responden mayoritas memiliki pendidikan menengah $(57,7 \%)$, dan persalinan primipara $(79,4 \%)$. Hal ini bisa mempengaruhi usia reproduktif lebih dominan mengalami persalinan prematur daripada usia muda ( $<20$ tahun) atau usia tua (>35 tahun). Sesuai dengan hasil penelitian yang dilakukan oleh Oroh et al., (2015) dan Wahyuni (2017).

Latar belakang ibu yang rendah menjadikan kurangnya pengetahuan tentang kesehatan ibu hamil, sehingga mereka tidak mengetahui cara menjaga kesehatan ibu terutama pada masa kehamilan (Oroh et al., 2015). Hasil yang sama juga diteliti oleh Wahyuni (2017) terdapat hubungan antara paritas dengan kelahiran prematur. Persalinan prematur lebih sering terjadi pada kehamilan pertama. Kejadiannya akan berkurang dengan meningkatnya jumlah paritasyang cukup bulan sampai dengan paritas keempat (Krisnadi, et al., 2009).

Berdasarkan karakteristik responden riwayat prematur sebelumnya, keguguran (Abortus), Ketuban Pecah Dini (KPD), dan pemeriksaan kehamilan tidak memiliki pengaruh yang mendukung faktor terjadinya 
persalinan prematur di RSUD Panembahan Senopati Bantul Yogyakarta. Berdasarkan hasil penelitian tidak sesuai dengan penelitian yang dilakukan oleh Niswah (2016) yaitu tidak ada hubungan yang bermakna antara usia dengan kejadian persalinan prematur. Teori pendukung menurut teori Wiknjosastro (2009) mengatakan bahwa umur ibu $<20$ tahun atau $>35$ tahun merupakan salah satu faktor predisposisi terjadinya persalinan prematur.

\section{Kesimpulan}

\section{KESIMPULAN DAN SARAN}

Berdasarkan hasil dan pembahasan dalam penelitian ini dapat disimpulkan bahwa sebagai berikut :

a. Usia ibu hamil di RSUD Panembahan Senopati Bantul Yogyakarta mayoritas usia reproduktif.

b. Persalinan prematur di RSUD Panembahan Senopati Bantul Yogyakarta mayoritas kejadian persalinan prematur sedang atau akhir.

c. Terdapat hubungan usia ibu hamil dengan kejadian persalinan prematur RSUD Panembahan Senopati Bantul Yogyakarta.

\section{Saran}

Berdasarkan hasil penelitian ini dapat dijadikan masukkkan sebagai berikut:

a. Saran Teoritis bagi Ilmu Keperawatan Maternitas

Hasil penelitian ini dapat menjadi bahan edukasi perawat untuk ilmu pengetahuan dalam bidang ilmu keperawatan, khususnya dalam ilmu keperawatan maternitas.

b. Saran Praktis

1) Bagi ibu hamil di RSUD Panembahan Senopati Bantul Yogyakarta

Diharapkan dapat dijadikan sebagai sumber informasi bagi ibu hamil untuk menjaga kehamilannya agar tidak mengalami persalinan prematur, dan melakukan pemeriksaan kehamilan secara teratur minimal 4 kali.

2) Bagi RSUD Panembahan Senopati Bantul Yogyakarta

Diharapkan penelitian ini dapat menjadi referensi bagi perawat dalam pemberian edukasi bagi ibu hamil dan ibu yang merencanakan kehamilan di RSUD Panembahan Senopati Bantul Yogyakarta.

3) Bagi mahasiswa STIKes Surya Global Yogyakarta

Diharakan penelitian ini dapat dijadikan wacana pembelajaran mahasiswa untuk menambah dan memperluas khasanah keilmuan.

4) Bagi Peneliti Selanjutnya

Diharapkan penelitian ini dapat menjadi bahan referensi untuk penelitian selanjutnya, dengan meneliti faktor lainnya seperti :

a) Faktor pendidikan dan faktor paritas.

b) Faktor Abortus, KPD, riwayat prematur sebelumnya, dan pemeriksaan kehamilan. 
c) Faktor yang dikendalikan diantaranya kehamilan dengan penyakit medis penyerta (DM, Anemia, penyakit jantung, hipertensi, kelainan uterus, kehamilan kembar dan inkompetensi serviks), kehamilan dengan infeksi, dan faktor genetik.

\section{UCAPAN TERIMA KASIH}

Penyusunan skripsi ini tidak akan selsesai tanpa bantuan dari berbagai pihak, baik secara langsung atau tidak langsung, maka dari itu peneliti mengucapkan terima kasih, kepada :

1. Orangtua, suami, dan keluarga yang selalu mendukung dan mendokan.

2. Dosen pembimbing ibu Viantika Kusumasari, S.Kep., Ns., M.Kep.

3. Pihak RSUD Panembahan Senopati Bantul Yogyakarta sebagai lokasi penelitian.

\section{DAFTAR PUSTAKA}

Al-Qur'an. Surat Al-Baqarah ayat 223.

Anasari, T., dan Pantiawati, I. 2016. Faktor yang Mempengaruhi Persalinan Preterm di RSUD Prof. Dr. Margono Soekarjo Purwokerto. Jurnal Kebidanan Vol. 8 No. 1. http://ejurnal.stikeseub.ac.id.view. Agustus 2016.

Arikunto, S. 2014. Prosedur Penelitian Suatu Pendekatan Praktis. Renika Cipta. Jakarta.

Binalole, V., Kaunang, E., dan Rampengan. 2015. Hubungan Kelahiran Prematur dengan Penyakit Jantung Bawaan di RSUP Prof. Dr. R. D. Kandou Manado tahun 2013-2014. Jurnal Unsrat. http://ejurnal.unsrat.ac.id.view. Juli 2016.

BKKBN. 2015. Profil Kesehatan Indonesia. BKKBN-Kemenkes. www.depkes.go.id.pusdatin. Januari 2016.

Departemen Kesehatan RI. 2009. Profil Kesehatan Indonesia. Depkes RI. Jakarta. . 2011. Profil Kesehatan Indonesia. Depkes RI. Jakarta.

Dinas Kesehatan RI. 2017. Profil Kesehatan Indonesia. Dinkes RI. Jakarta.

DIY. 2017. Profil Kesehatan Daerah Istimewa Yogyakarta (DIY). Dinkes DIY. Yogyakarta.

Bantul. 2017. Profil Kesehatan Kabupaten Bantul-DIY. Dinkes Bantul. Yogyakarta.

Hidayati, L. 2016. Faktor Resiko Terjadinya Persalinan Prematur Mengancam RSUD Dr. Soetomo Surabaya. Perpustakaan Universitas Airlangga. http://repository.unair.ac.id/id/eprint/39917. Agustus 2017.

InfoDATIN. 2018. Pusat Data dan Informasi Kementrian Kesehatan RI. ISSN 24427659. http://infodatin. preterm.com. 3 april 2018

Krisnadi, Effendi, dan Pribadi, A. 2009. Prematuritas. PT Refika Aditama. Bandung.

Ningrum, Nurhamidi, dan Yusti. 2017. Hubungan Umur, Paritas dan Kejadian Anemia Dengan Kejadian Persalinan Prematur Di Rsud Dr. H. Moch. 
Ansari Saleh Banjarmasin Tahun 2016. Dinamika Kesehatan, Vol. 8 No.1, Juli 2017. http://garuda.ristekdikti.go.id. 22 November 2017.

Niswah, F. 2016. Faktor yang Mempengaruhi Persalinan Prematur di RSUD Tegurejo Semarang. Library UNNES. http://library.unnes.niswah. Mei 2017.

Notoatmodjo, S. 2012. Metodologi Penelitian Kesehatan. Rineka Cipta. Jakarta.

Nugroho, T. 2012. Obstetri dan Ginekologi. Nuha Medika. Yogyakarta.

Nursalam, 2017. Metodologi Penelitian Ilmu Keperawatan: Pendekatan Praktis, edisi 3. Salemba. Jakarta.

Oroh, S., Suparman, E., dan Tendean, H. 2015. Karakteristik Persalinan Prematur di RSUP Prof. Dr. R. D. Kandou Manado. Jurnal e-Clinic (eCI) Vo. 3 No. 2. http://ejurnal.unsrat.ac.id. Agustus 2015

Prawirohardjo, S. 2016. Ilmu Kebidanan. PT Bina Pustaka. Jakarta.

Sugiyono. 2017. Metode Penelitian Kuantitatif, Kualitatif, dan RD. Alfabeta,. Bandung.

Sulistiarini, D., Berliana, dan Sarni, M. 2016. Faktor-Faktor Yang Mempengaruhi Kelahiran Prematur Di Indonesia: Analisis Data Riskesdas 2013. EJournal WIDYA Kesehatan Dan Lingkungan, Vol. 1 No.2. http://media.neliti.com/media/publications/36815.pdf. Maret 2016

Wahyuni, R., dan Rohani, S. 2017. Faktor-faktor yang mempengaruhi persalinan preterm. Jurnal Aisyah Vol. 2 No. 1. https://doi.org/10.30604/jika.v2i1.33.

WHO. 2012. Born to Soon. The Global Action Report on Pretem Birth. Jurnal World Health Organozation. https://www.who.int. 3 April 2012.

Zainal, H, M. Dahlul, A.S. Soelar, dan TT, Su. 2019. Cost of Preterm Birth During Initial Hospitalization: A Care Provider's Perspective. Plos One. https://doi.org/10.1371/journal.pone.0211997. 25 Juni 2019. 